\title{
Ressentimentos e estereótipos: ensaio sobre as representaçóes a respeito do português no Brasil (século XIX)
}

\author{
Igor José de Renó Machado*
}

\section{RESUMO}

Neste ensaio proponho uma hipótese para a construção da imagem do português no Brasil. No senso comum brasileiro, a imagem estereotipada de um português pouco inteligente é compartilhada nacionalmente, sendo substrato para piadas e referências pouco elogiosas aos sujeitos $\mathrm{da}$ ex-metrópole. Busco aqui uma interpretação possível para o surgimento dessas representaçóes coletivas sem, contudo, procurar dar uma resposta que esgote todas as possibilidades.

Palavras-chave: imigração portuguesa no Brasil; estereótipos; conflitos de classe; mercado de trabalho; preconceito

\section{ABSTRACT}

In this essay I propose a hypothesis for the construction of the image of Portuguese people in Brazil. In Brazilian common sense, the stereotypical image of Portuguese people as unintelligent is spread throughout the country, and is the source of jokes and unflattering references to the population that was once our colonizers. I seek here a possible interpretation for the emergence of these collective representations without seeking to provide an answer that exhausts all possibilities, however.

Keywords: Portuguese migration to Brazil; stereotypes; class conflicts; labor market; prejudice.

\section{RESUMEN}

En este ensayo propongo una hipótesis para la construcción de la imagen del portugués en Brasil. En el sentido común brasileño, la imagen estereotipada de un portugués poco inteligente es compartida nacionalmente, siendo base para burlas y referencias poco elogiosas a los sujetos de la antigua metrópoli. Busco aquí una posible interpretación para el surgimiento de esas representaciones colectivas, pero sin intentar dar una respuesta que agote todas las posibilidades.

Palabras claves: Inmigración portuguesa en Brasil; estereotipos; conflicto de clase; mercado de trabajo, prejuicio. 
Neste ensaio proponho uma hipótese para a construçáo da imagem do português no Brasil. No senso comum brasileiro, a imagem estereotipada de um português pouco inteligente é compartilhada nacionalmente, sendo substrato para piadas e referências pouco elogiosas aos sujeitos da ex-metrópole. Busco aqui uma interpretação possível para o surgimento dessas representaçóes coletivas sem, contudo, procurar dar uma resposta que esgote todas as possibilidades. Avento uma hipótese plausível, que pode ser vista como uma determinante entre outras, mas que certamente tem uma grande importância entre as demais. Voltarei a atenção para o século XIX, no qual a formação conflituosa de novas disposiçôes do mercado de trabalho e as ondas antilusitanas parecem ter uma relevância especial na construção das imagens de longa duração sobre o português.

Como é sabido, não havia espaço para nacionais no comércio a varejo brasileiro, pois o trato comercial era feito majoritariamente por portugueses que emigravam para o Brasil em grande número. $\mathrm{O}$ antilusitanismo tem íntima relação ao domínio ferrenho das praças de comércio brasileiras, sempre controladas por portugueses que chegavam ao Brasil. Essa imigração é obviamente correspondente a de tipo mais qualificado, ${ }^{1}$ e não se refere ao "engajado". Mas mesmo esse último, migrante pobre e sem conexôes familiares na colônia, tinha mais facilidades para conseguir emprego no comércio que qualquer brasileiro nativo. Essa situação gerou campanhas para a nacionalização do comércio e tumultos, quebra-quebras, espancamentos e até mortes. ${ }^{2}$

O objetivo do texto é produzir uma reflexão sobre a relação entre o ressentimento como um sentimento mobilizado politicamente e a produção de um conjunto de estereótipos sobre o português no Brasil. Considerarei o século XIX como uma sucessão de momentos fundamentais para explicar a construção desses estereótipos, culminando no jacobinismo antilusitano da República Velha. Deve-se destacar que o período de tempo extenso esconde uma complexidade variada, que será resumida apenas aos temas que aqui nos interessam no limite de um ensaio. Necessariamente, muito é deixado de fora a fim de mobilizar uma discussão pertinente sobre o tema do ressentimento e dos estereótipos.

Vale destacar que se o antilusitanismo e os estereótipos sobre o português são importantes na história brasileira, podemos ver esse exemplo como apenas mais um caso da relação entre a produção de estereótipos e manipulação de ressentimentos. O que aconteceu no século XIX no Brasil, em termos gerais, não é muito diferente do que acontece agora no começo do século XXI na Europa com relação aos refugiados e imigrantes, ou mesmo em relação ao recente processo de demonização coletiva de um partido político de centro-esquerda

\footnotetext{
${ }^{1}$ ALVES, Jorge Fernandes. Os brasileiros. Emigração e retorno no Porto oitocentista. Porto: Edição do Autor, 1994.

${ }^{2}$ Destaco que não tratarei do lugar e do papel das associaçóes de imigrantes portugueses e nem, genericamente, do ponto de vista da "colônia portuguesa" sobre os fenômenos aqui explorados. Esta é uma tarefa para outro ensaio.
} 
pela manipulação de certos ressentimentos e preconceitos correntes na sociedade brasileira. Entender esse processo do antilusitanismo é, portanto, uma forma de entender mecanismos muito persistentes de produção de estereótipos, preconceitos e racismos.

\section{Mercado de trabalho, competição e racialização}

Se considerarmos que a imagem do português formulada pela nação brasileira foi por excelência a do "burro", e, ainda, que esta foi uma resposta antilusitana ao monopólio do comércio por parte dos portugueses e às estratégias de enriquecimento lusitanas no Brasil, pode-se afirmar que, inicialmente, essa visão era uma forma de ressentimento ${ }^{3}$ por parte dos brasileiros, que lutavam com as armas que tinham à disposição, entre elas a desmoralização simbólica. Como memória do ressentimento, os estereótipos revelam mais sobre quem os formula do que sobre quem é descrito. Os estereótipos são uma forma de não conhecimento sobre seu objeto, e revelam algo sobre quem perpetua as imagens agressivas e rudimentares.

Essa contraposição entre estereótipos esclarece algo sobre o lugar do qual falam quem os proferem (suas posicionalidades, segundo Hallit): o português, com seu inevitável ranço colonialista, e o brasileiro, inconformado com a continuidade da dominação portuguesa do comércio. Esse é o ponto. Entretanto, as memórias populares, as tradiçôes orais, têm vida própria como manifestaçôes da organização simbólica. $\mathrm{O}$ que era ressentimento em um momento pode tornar-se vítima aleatória do humor popular, e o momento em que isso acontece é difícil de documentar. Mas é preciso entender que as atuais piadas sobre os portugueses têm uma origem política de resistência e revolta populares, e que esse processo, de certa forma, fechou as portas a um reconhecimento do que é Portugal durante o século XX.

Talvez seja essa memória coletiva que acentua o desconhecimento brasileiro de tudo que se passa em Portugal desde a proclamação da República. O estereótipo, como não conhecimento, é também um inibidor, pois impede que se veja o outro por detrás da couraça criada, e com a qual se imagina conhecê-lo, alvo das indignaçôes populares. Do lado brasileiro, a presença da imigraçáo "qualificada" portuguesa produziu uma dependência acentuada ao

\footnotetext{
${ }^{3}$ Cf. ANSART, Pierre. História e memória dos ressentimentos. In: BRESCIANI, Stella; NAXARA, Márcia (Orgs.). Memória (res)sentimento, indagaçôes sobre uma questão sensivel. Campinas: Ed. Unicamp, 2001; ANSART-DOURLEN, Michèle. O ressentimento — as modalidades de seu deslocamento nas práticas revolucionárias. Reflexôes sobre o uso da violência. In: BRESCIANI, Stella; NAXARA, Márcia (Orgs.). Memória (res)sentimento, indagaçóes sobre uma questão sensivel, op. cit.; ZAWADSKI, Paul. O ressentimento e a igualdade: contribuição para uma antropologia filosófica da democracia. In: BRESCIANI, Stella; NAXARA, Márcia (Orgs.). Memória (res)sentimento, indagaçôes sobre uma questão sensivel, op. cit.; NIETZSCHE, Friedrich. A genealogia da moral. 3. ed. Lisboa: Guimarães e C. A. Editores, 1976; SCHELER, Max. Da reviravolta dos valores. Petrópolis, RJ: Vozes, 1994 [1972] e FREUD, Sigmund. Civilization and its Discontents (1930 [1929]). In: FREUD, Sigmund. The Standard Edition of the Complete Psychological Works of Sigmund Freud. Volume XXI (1927-1931). 3. ed. Toronto: The Hogart Press Limited, 1968.

${ }^{4}$ HALL, Stuart. A identidade cultural na pós-modernidade. Rio de Janeiro: DP\&A, 2002.
} 
centro financeiro do Porto. Durante o século XIX, o exclusivismo e o caráter oligopolista da rede de comércio a varejo português foi a marca predominante. ${ }^{5}$ Para Alencastro, a dominação exclusivista desse comércio é uma das fontes da lusofobia do século XIX, principalmente por privar as classes médias brasileiras do acesso aos poucos empregos disponíveis.

É preciso deixar claro que há diferenças marcantes entre os dois grandes períodos abordados (período pós-independência na primeira metade do século XIX e a vaga de imigração da parte final da segunda metade do século XIX). A rivalidade entre brasileiros e portugueses não pode ser vista da mesma forma nos dois períodos já que durante todo o Primeiro Reinado, mesmo entre a elite, a distinção entre "brasileiros" e "portugueses" não era um dado adquirido. Lessa chega a afirmar que durante o primeiro reinado viu-se um cenário "sem tensão com os portugueses". ${ }^{6}$ Já no período da República Velha, o antilusitanismo, associado à crise econômica do final do século XIX, promoveu outra ordem de conflitos, levando até a uma reação diplomática portuguesa ao antilusitanismo corrente no Brasil.

Florentino $^{7}$ demonstra que os traficantes de escravos no Rio de Janeiro entre 1780 e 1830 eram cerca de $10 \%$ dos comerciantes, mas detinham entre $1 / 3$ e $1 / 5$ do comércio com as praças de Portugal, incluindo Goa e Macau, e centralizavam o fornecimento de grande parte dos gêneros de escambo trocados depois nos portos africanos. ${ }^{8}$ Os traficantes atuavam em várias outras esferas de comércio de forma internacionalizada. Esse dinheiro era investido principalmente em prédios urbanos, indicando a grande urbanização do Rio de Janeiro na primeira metade do século XIX. Esses comerciantes detinham o monopólio virtual do sistema de créditos, moradias urbanas, terras, dinheiro circulante e de escravos. Alguns desses traficantes eram portugueses, filhos de portugueses, e outros foram "torna-viagens", como José Bernardino de Sá, maior traficante ilegal depois de 1830, que voltou a Portugal em 1851 e se transformou no barão de Vila Nova do Minho.

Além de evidenciar a participação dos portugueses de torna-viagens no tráfico de escravos - como de resto grande parte da caricatura dos literatos do século XIX denuncia - o fato de parte significativa do capital negreiro ser investida no mercado imobiliário permite-nos estabelecer relaçôes com um dos principais motivos de tumultos antilusitanos, além do domínio do comércio a varejo: a extorsão por meio de aluguéis aviltantes. Como grande parte dos imóveis estava nas mãos de negreiros, é de se imaginar uma relação entre a propriedade de prédios urbanos por portugueses e o tráfico. Um dos instrumentos de domínio comercial e político dos portugueses e descendentes imediatos - a propriedade de prédios urbanos - foi produzido pelo comércio de escravos.

\footnotetext{
${ }^{5}$ ALENCASTRO, Luiz Felipe. Escravos e proletários. Novos Estudos Cebrap, n. 21, p. 30-57, jul. 1988.

${ }^{6}$ LESSA, Carlos. Nação e nacionalismo a partir da experiência brasileira. Estudos Avançados, v. 22, n. 62, p. 237-256, 2008. p. 242.

${ }^{7}$ FLORENTINO, Manolo. Um comércio singular: tráfico e traficantes de africanos no Rio de Janeiro (17901830). Oceanos, n. 44, p. 43, out/dez. 2000.

${ }^{8}$ Ibidem, p. 53.
} 
As séries de estereótipos sobre ganância, avidez e superexploração estão relacionadas a esse controle que excluía premeditadamente os brasileiros. Esses estereótipos sáo estendidos aos "engajados" portugueses que disputaram o mercado de trabalho mais baixo nas grandes cidades. Eles fugiam das fazendas à medida que se alastravam as informaçôes sobre as condiçóes de trabalho no seu interior, ${ }^{9}$ procurando principalmente o Rio de Janeiro, onde competiam com a mão de obra livre e liberta do século XIX, causando grandes mudanças nas relaçôes entre salários e preços dos escravos. A chegada desses trabalhadores desestimulou o emprego dos cativos nas atividades urbanas. ${ }^{10}$ Como ainda demonstra Alencastro, ${ }^{11}$ os dois ciclos de crescimento da imigração portuguesa no século XIX (1850-1859 e 1869-1875), compostos principalmente pelos "engajados", resultam no rebaixamento de preços dos escravos não qualificados, levando à diminuição da população cativa no Rio de Janeiro. Isso acontecia porque era mais vantajoso ao senhor do escravo não qualificado vendê-lo para as fazendas do interior. Se o escravo era qualificado, seu valor era maior na cidade do que no campo e não era vantajoso vendê-lo. Isso fazia o senhor se interessar pelo único comprador possível desse escravo: o próprio escravo. Após 1875, com a diminuição da imigração, o quadro mudou e

um outro contingente de trabalhadores — os brasileiros livres e libertos - toma o lugar dos portugueses. Em suma, o mercado de trabalho do Rio de Janeiro conhece três fases bem distintas no decurso do século XIX: uma primeira fase, africana, estende-se até 1850; uma fase luso-africana, que vai até 1875 e, por fim, uma fase luso-brasileira. ${ }^{12}$

A chegada em massa dos "engajados" produziu uma camada de proletários que surpreendeu tanto aos brasileiros, que se depararam com a aberração de imigrantes brancos pobres trabalhando lado a lado com livres e libertos, quanto aos portugueses estabelecidos. Segundo Alencastro, o apelido de galego é produzido inicialmente entre os portugueses, para depois virar mote nas lutas antilusitanas, assim como o termo "marinheiro":

Às vezes, conflitos opunham os comerciantes portugueses a seus compatriotas. No início, é bem provável que o epíteto "galego" tenha sido utilizado pejorativamente pelos comerciantes portugueses para designar os subproletários portugueses que aceitavam tarefas similares às que os verdadeiros galegos emigrados da província espanhola da Galícia executavam em Lisboa. Em seguida os brasileiros denominaram "galegos" a totalidade dos portugueses estabelecidos no Brasil). ${ }^{13}$

\footnotetext{
${ }^{9}$ ALENCASTRO, Luiz Felipe. Escravos e proletários, op. cit., p. 38-39.

${ }^{10}$ Ibidem, p. 41.

${ }^{11}$ Ibidem, p. 43 e ss.

${ }^{12}$ Ibidem, p. 43.

${ }^{13}$ Ibidem, p. 50, nota 107.
} 
As consequências desse processo foram acentuadas por uma política racial do governo imperial, pois Alencastro ${ }^{14}$ mostra como foi proibido, em 1862, o emprego de escravos nas obras da estrada de ferro d. Pedro II, entre outras proibições do gênero. Em razão da chegada de grandes números de imigrantes portugueses houve uma redução nas atividades assalariadas das populaçóes escravas. ${ }^{15}$

Segundo Ribeiro, no século XIX,

os incitamentos antilusitanos, a necessidade de construçáo de uma identidade calcada na diferença com relação ao outro - estrangeiro, em geral, e português, em particular - e a situação da população pobre e marginalizada da cidade, servira como uma bomba-relógio. ${ }^{16}$

Esta autora também indica a competição no mercado de trabalho entre portugueses pobres e escravos e, em outro livro, ${ }^{17}$ que trata do final do século XIX e começo do XX, afirma que os portugueses aumentaram o exército de reserva no Rio de Janeiro e pressionaram o mercado, o que os fizeram "inimigos do povo". A questão então era se a competiçấo entre essas categorias diminuiu o preço médio do salário, o que os números de Alencastro confirmam, ou se estimulou a racialização do mercado de trabalho, ou seja, a escolha voluntária de brancos para fazer os mesmos serviços por maiores salários.

Provavelmente, ocorreu uma confluência entre os dois fatores, conduzindo a uma baixa no salário médio $e$ a uma racialização do mercado de trabalho. Ora, essa racialização só pode acentuar ainda mais a revolta popular antilusitana, que se via confrontada com a estrutura lusitana de domínio do comércio a varejo, que era inacessível aos brasileiros em geral, e depois com a preferência aos lusitanos nos empregos que não exigiam qualificação específica. Ribeiro afirma que as massas populares que praticavam os atos antilusitanos eram bem específicas: negros e mulatos. ${ }^{18}$ Segundo a autora, "As lutas davam-se entre a população 'de cor' e os 'brancos', a população 'de cor' e os portugueses natos, 'brasileiros' e 'portugueses',

\footnotetext{
${ }^{14}$ Ibidem, p. 43, nota 70.

${ }^{15}$ Eduardo da Silva, ao descrever, por meio da história de Dom Obá II, um pouco do cotidiano da "África Pequena" - verdadeiro gueto negro no Rio de Janeiro do século XIX, afirma que "para os brasileiros da África Pequena, a política imigrantista não representava apenas 'a substituição do trabalho escravo', mas, principalmente, o estreitamento e quase colapso de seu mercado de trabalho tradicional" (SILVA, Eduardo da. Dom Obá II d'África, o príncipe do povo: vida, tempo e pensamento de um homem livre de cor. Sáo Paulo: Companhia das Letras, 1997, p. 155)

${ }^{16}$ RIBEIRO, Gladys Sabina. Pés-de-chumbo e garrafeiros: conflitos e tensóes nas ruas do Rio de Janeiro no Primeiro Reinado (1822-1831). Revista Brasileira de História, v. 12, n. 23/24, p. 142, 1992. Aqui estamos lidando com as características do antilusitanismo da República Velha.

${ }^{17}$ RIBEIRO, Gladys Sabina. Mata galegos. Os portugueses e os conflitos de trabalho na República Velha. São Paulo: Brasiliense, 1990.

${ }^{18}$ RIBEIRO, Gladys Sabina. Pés-de-chumbo e garrafeiros: conflitos e tensôes nas ruas do Rio de Janeiro no Primeiro reinado (1822-1831), op. cit., p. 147.
} 
'povo' e 'Povo". ${ }^{19}$ As questóes de construção de uma identidade nacional eram marcadas por uma série de tensôes de caráter racial, além daquela de nacionalidade. Assim, "a experiência compartilhada da 'gente de cor', nas ruas do Rio de Janeiro, dava-lhes um caráter de classe. Lutavam contra a escravidão e contra os 'brancos', na sua maioria portugueses de nascimento ou luso-descendentes". ${ }^{20}$ Cabe lembrar que essas reflexóes se relacionavam com o Rio de Janeiro, e que as tensôes poderiam ser diferenciadas no resto do país, como argumenta a autora. Mesmo assim é possível dizer que a memória preconceituosa contra os portugueses é uma memória que nasceu com a resistência negra e mulata no Rio de Janeiro, a princípio, e se espalhou pelo país tornando-se gradualmente uma memória nacional desracializada.

$\mathrm{Na}$ transição do trabalho escravo para o livre, segundo Ribeiro, ${ }^{21}$ os portugueses eram associados à exploração comezinha e cotidiana: no roubo das medidas, na superexploração dos empregados etc. É dessa perspectiva, certamente, que surgiram os estereótipos de avareza, "pão-durice" e esperteza mal-intencionada. A imagem acentuava-se nas crises econômicas, que fizeram dos portugueses os bodes expiatórios das dificuldades, em um processo semelhante ao que ocorre hoje em dia na Europa em relaçáo aos imigrantes. A diferença é que aqui os portugueses dominavam o mercado de trabalho do comércio a retalho e, depois, com a imigração dos mais pobres, passaram a competir no mercado de trabalho não qualificado - espaço que era de brasileiros negros e pardos, segundo as concepçóes da época.

Rowland $^{22}$ afirma que os estereótipos sobre os portugueses deviam-se à concorrência no mercado de trabalho e à resistência à ética do trabalho por parte dos brasileiros. Aceita o pressuposto das elites da época, o de que os portugueses eram portadores natos de uma ética do trabalho. O corolário dessa afirmação é que o "povo" brasileiro, composto essencialmente por negros e mestiços na visão da elite, era preguiçoso e ruim para o trabalho. É preciso ficar atento para não reproduzir o discurso racializado das elites do século XIX — que se perpetua até hoje. Rowland reduz os estereótipos nativos sobre os portugueses, aos quais chamo de "memória de resistência", às práticas discursivas não localizadas, etéreas - frases do tipo "os estereótipos se criam", "desenvolvem-se estereótipos" — produzidas na busca de uma identidade nacional contrastante. É como se o comerciante português a partir do qual se modelaram os estereótipos fosse uma ilusão. Ora, vendo a trajetória de retorno desses imigrantes e o projeto que cultivavam ao vir para o Brasil, é certo que se entende o tipo predatório de enriquecimento e, ainda mais, a fama de sovina, exploradores e de levarem consigo as riquezas aqui adquiridas. Mas Rowland também põe na devida perspectiva esse tipo de imigrante, ligado ao comércio a varejo, demonstrando como era minoria no final do século XIX, em relação ao grande número de portugueses pobres que emigravam para o Brasil. Identifica, a partir de 1870, mudanças nos

\footnotetext{
${ }^{19}$ Ibidem, p. 150.

${ }^{20}$ Ibidem, p. 163.

${ }^{21}$ RIBEIRO, Gladys Sabina. Mata galegos. Os portugueses e os conflitos de trabalho na República Velha, op. cit.

${ }^{22}$ ROWLAND, Robert. Portugueses no Brasil independente: processos e representaçôes. Oceanos, n. 44, p. 12, out./dez. 2000.
} 
estereótipos, paralelas as que venho mencionando e que Alencastro ${ }^{23}$ levantou: com a entrada de imigrantes pobres que concorriam no mercado de trabalho não qualificado, a imagem do "burro" passou a ser veiculada. Rowland defende que o registro dos estereótipos passou a ter uma duplicidade: o explorador e o burro. Diga-se que a segunda suplantou a primeira e permanece hoje como centro da representação sobre o português no Brasil.

As imagens de exploração referem-se aos imigrantes qualificados que especificamos anteriormente, e não aos "engajados" da segunda metade do século. Foram os primeiros que tiveram possibilidades efetivas de enriquecer, devido às redes de parentesco e às solidariedades da colônia portuguesa. Esses eram trabalhadores modelo, pois se entranhavam em uma relação de paternalismo com os patróes portugueses, como afirma Ribeiro, na esperança de uma sociedade futura, de um casamento com a filha do chefe etc. Em minha opinião, são as condiçốes estruturais nas quais trabalhavam que os permitiam enriquecer, principalmente o imigrante que vinha amparado por redes familiares de sustentação, não o "engajado". Esse último participou, juntamente com os demais trabalhadores, nas reivindicações trabalhistas e nos movimentos de protesto, quando era operário, como demonstra Ribeiro.

A exploração a que os portugueses empregados no comércio a varejo se submetiam era reflexo do que Ribeiro chama de "paternalismo negociado", mas que — imagino — funcionava apenas para os imigrantes bem colocados estruturalmente, e não para os demais. Para além disso, havia a intensa racialização do mercado de trabalho, a partir das concepçóes racistas da elite brasileira, que impôs o rótulo de preguiçosos aos negros (africanos ou brasileiros) e mulatos, justificando as políticas de imigração amplamente racializadas: o ethos do trabalho era uma coisa de brancos. $\mathrm{O}$ ressurgimento do antilusitanismo tem relação com a competição pelo mercado de trabalho não qualificado, demonstrado por Alencastro, ${ }^{24}$ e foi esse processo que modelou a nova roupagem dos estereótipos em relaçáo aos portugueses que chegou a nós hoje em dia: agora são os portugueses burros e torpes.

\section{Ressentimento e estereótipos}

A análise da relação entre ressentimento e memória pode ser interessante para entender o caso dos conflitos antilusitanos e os resultados simbólicos desses embates. Ansart ${ }^{25}$ faz uma análise da historiografia do tema do ressentimento e indica seus três principais autores: Nietzsche, Scheler e Merton. É Nietzsche ${ }^{26}$ quem debate a questão de forma a descrever o ressentimento que surge de algum conflito em sua interiorização e denegação. ${ }^{27}$ Ao longo do tempo, esse ódio

\footnotetext{
${ }^{23}$ ALENCASTRO, Luiz Felipe. Escravos e proletários, op. cit.

${ }^{24}$ Idem.

${ }^{25}$ ANSART, Pierre. História e memória dos ressentimentos, op. cit.

${ }^{26}$ NIETZSCHE, Friedrich. A genealogia da moral, op. cit.

${ }^{27}$ ANSART, Pierre. História e memória dos ressentimentos, op. cit., p. 16-17.
} 
e esse ressentimento são interiorizados pelos dominados e modificados em valor positivo: surge uma humildade resignada, um ódio recalcado que pode ser transformado, eventualmente, em "ódio de si mesmo". ${ }^{28}$ Max Scheler ${ }^{29}$ abandona a perspectiva histórica de Nietzsche por uma análise dos diferentes componentes do ressentimento, universalizáveis a qualquer povo. ${ }^{30}$

Merton, ${ }^{31}$ por sua vez, dá ênfase ao sistema socioafetivo que resulta do ressentimento, e sua definição tem três elementos:

O primeiro compóe-se de sentimentos difusos de ódio, de inveja e de hostilidade; o segundo é a sensação de ser impotente para exprimir de forma ativa estes sentimentos; o terceiro é a experiência continuamente renovada de impotente hostilidade. ${ }^{32}$

Haroche ${ }^{33}$ também define o ressentimento por meio dessas características levantadas por Merton.

Não concordando com a condição de imobilidade a que o ressentimento condena as pessoas na reflexão desses autores, Ansart propóe que se acrescentem novas perspectivas na consideração do ressentimento. A primeira é que os ressentimentos devem ser vistos no plural, de forma a dar conta de diferentes situaçôes. No caso do ressentimento antilusitano brasileiro, por exemplo, é possível distinguir o ressentimento racializado das populaçôes pardas e negras em relação aos portugueses engajados brancos e pobres, do ressentimento "econômico" de certa classe média brasileira em relação à elite portuguesa, segundo a afirmação de Alencastro. ${ }^{34}$ Esses dois ressentimentos impulsionaram as revoltas, mas também configuraram uma possibilidade de manipulação do ressentimento. Esta última é analisada por Ansart-Dourlen. ${ }^{35}$

Nietzsche, por exemplo, distingue dois tipos de ressentimento: o dos dominados (marcado pela fraqueza) e o dos dominantes (desprezo e ódio em relação à revolta dos dominados). Essa

\footnotetext{
${ }^{28}$ Idem.

${ }^{29}$ SCHELER, Max. Da reviravolta dos valores. Petrópolis, RJ: Vozes, 1994 [1972].

30 "[Ressentimento é] uma atitude mental duradoura, causada pela repressão sistemática de certas emoçóes e afetos que são normais da natureza humana. A repressão dessas emoçóes leva a uma tendência constante de se permitir atribuir valores incorretos e juízos de valor correspondentes. As emoçóes e afetos primordialmente referidos são vingança, ódio, malícia, inveja, o impulso a diminuir e desprezar" (SCHELER apud KONSTAN, David. Ressentimento - história de uma emoção. In: BRESCIANI, Stella; NAXARA, Márcia (Orgs.). Memória (res) sentimento, indagaçóes sobre uma questấo sensível, op. cit., p. 62.

${ }^{31}$ MERTON, Robert King. Eléments de théorie et de méthode sociologique. Paris: Plon, 1965.

${ }^{32}$ MERTON apud ANSART, Pierre. História e memória dos ressentimentos, op. cit., p. 18.

${ }^{33}$ HAROCHE, Claudine. Elementos para uma antropologia política do ressentimento: laços emocionais e progressos políticos. In: BRESCIANI, Stella; NAXARA, Márcia (Orgs.). Memória (res)sentimento, indagaçóes sobre uma questão sensivel, op. cit., p. 334.

${ }^{34}$ ALENCASTRO, Luiz Felipe. Escravos e proletários, op. cit.

${ }^{35}$ ANSART-DOURLEN, Michèle. O ressentimento - as modalidades de seu deslocamento nas práticas revolucionárias. Reflexões sobre o uso da violência, op. cit.
} 
distinção nietzscheana, inclusive, é base da distinção que Zawadzki ${ }^{36}$ propóe para a análise da dinâmica dos ressentimentos: por um lado ter-se-ia o ressentimento gerado pela aspiração da igualdade (dos dominados) e, por outro, o ressentimento dos que recusam a igualdade (os dominantes ou estabelecidos). Este último seria o gerador de racismos contra os outsiders.

Konstan, ${ }^{37}$ por outro lado, identifica três conotaçóes para o termo ressentimento: psicológico, social e existencial. O primeiro é relativo ao nível pessoal e revela-se mediante uma desfeita, uma injúria, sendo uma emoção não fugaz. O sentido social tem relação com a percepção de um grupo de ser injustiçado na hierarquia de status. Há um sentimento de pertencimento a um grupo e uma experiência de preconceito e discriminação (a sociologia de Merton trataria desse tipo de ressentimento). Ao sentido existencial estão ligados os trabalhos de Nietzsche e Scheler, ambos já mencionados. O autor defende ${ }^{38}$ também que se encontra mais ressentimento social e psicológico nas sociedades democráticas, pela promessa de igualdade que não se verifica.

Outras dimensóes a acrescentar às analises sobre o ressentimento, segundo Ansart, seriam as ênfases não apenas nos indivíduos, mas também nas representaçôes, ideologias e imaginários que são reveladores no devir do ressentimento, por um lado e, por outro, a consideraçáo do papel dos porta-vozes do ressentimento (escritores, líderes carismáticos, seitas etc.), pois o papel dos provocadores pode elucidar muitos processos históricos de exasperação dos ressentimentos. Esses dois pontos são fundamentais para entendermos o ressentimento antilusitano no Brasil, que criou poderosos imaginários que se perpetuam até nossos dias, o que nos permite especular sobre seu caráter estruturante. Foram também divulgados por porta-vozes ativos na história do final do século XIX, como os jacobinos, analisados por Ribeiro. ${ }^{39}$

O último ponto destacado por Ansart é em relação às consequências e manifestaçôes do ressentimento. Se os três autores clássicos que tratam do ressentimento hesitam sobre este ponto, destacando sua tendência à imobilidade, Ansart procura entender a ação que é resultante do ressentimento. Ou seja, restituir aos sujeitos o papel de "criadores" de história, e vê-los não apenas como repositórios de um ressentimento autodestrutivo. $\mathrm{O}$ ressentimento é dinâmico, criador de valores (como afirmava Scheler), assim,

a questão essencial colocada, às vezes de difícil resposta, é a necessidade de compreender e explicar como o ressentimento se manifesta, a quais comportamentos serve de fonte e que atitudes e condutas inspira, consciente ou inconscientemente. ${ }^{40}$

\footnotetext{
${ }^{36}$ ZAWADSKI, Paul. O ressentimento e a igualdade: contribuição para uma antropologia filosófica da democracia, op. cit.

${ }^{37}$ KONSTAN, David. Ressentimento — história de uma emoção, op. cit.

${ }^{38}$ Ibidem, p. 67.

${ }^{39}$ RIBEIRO, Gladys Sabina. A guerra dos portugueses no Rio de Janeiro no final do século XIX. Oceanos, n. 44, p. 79, out./dez. 2000.

${ }^{40}$ ANSART, Pierre. História e memória dos ressentimentos, op. cit., p. 21.
} 
Entre outras decorrências da ação, ele lembra a capacidade que a manifestação do ódio recalcado tem para constituir a coesão no interior de grupos, caso que podemos usar para pensar na unidade da ação antilusitana, que juntava diferentes classes contra um inimigo comum.

Esse raciocínio pode ser visto a partir de uma perspectiva de longo prazo, quando se dá a perenidade de um profundo desprezo pelo dominados ou pelos ex-dominados. No caso da relação entre as elites portuguesas e o Brasil, é possível falar de um ressentimento imperial que se perpetua nas formas de pensamentos coloniais que se sucedem a partir da independência do Brasil: darwinismo social, lusotropicalismo, lusofonia. Todas essas formas ideológicas têm em comum uma separação radical entre os civilizados (dominadores) e os primitivos (dominados). Sugiro que o papel do Brasil produziu nas elites portuguesas um grande ressentimento estruturante, criador de imaginários, ideias e crenças que reafirmam a subalternidade da ex-colônia no plano simbólico.

Seguindo a análise freudiana em $O$ mal-estar na civilização, ${ }^{41}$ Ansart afirma que há uma necessidade permanente, em qualquer sociedade, de encontrar inimigos a serem odiados, por quem se deve nutrir ressentimentos. A construção de inimigos seria uma das "necessidades normativas" da cultura. ${ }^{42}$ Porém, há sociedades mais ou menos dispostas a esse processo, o que inaugura um debate de base que opõe sociedades hierárquicas, em que a naturalização da diferença diminui a intensidade do ressentimento, a sociedades democráticas, em que a promessa não cumprida da igualdade estimula o ressentimento dos oprimidos. Esse debate é retomado por Zawadzki, ${ }^{43}$ transformando essa oposição em outra, entre pré-modernidade (sistemas não igualitários) e modernidade (sistemas com a pretensão de serem igualitários). O viés eurocêntrico (Amin, ${ }^{44}$ Latouche ${ }^{45}$ e Said ${ }^{46}$ ) é evidente, pois o parâmetro dado para discutir a dinâmica do ressentimento é um padrão político arbitrário (a democracia), e as comparações são sempre muito levianas, como, por exemplo, afirmar que o ressentimento em sociedades hierárquicas é menor.

Galvão define sua interpretação de ressentimento desta forma:

[o] ressentimento entendido no sentido nietzscheano do termo e modificado por Scheler e Merton participa na produção e na reprodução de um conjunto de predisposiçôes a certas atitudes e posturas - um habitus, como propóe Bourdieu — que medeia as relaçôes políticas no interior do regime imperial e, sugiro, torna-se condição necessária para a sua existência e reprodução. ${ }^{47}$

\footnotetext{
${ }^{41}$ FREUD, Sigmund. Civilization and its discontents (1930 [1929]), op. cit.

${ }^{42}$ ANSART, Pierre. História e memória dos ressentimentos, op. cit., p. 25.

${ }^{43}$ ZAWADSKI, Paul. O ressentimento e a igualdade: contribuição para uma antropologia filosófica da democracia, op. cit.

${ }^{44}$ AMIN, Samir. Eurocentrism. Nova York: NYU Press, 1989.

${ }^{45}$ LATOUCHE, Serge. The Westernisation of the World. The Significance, Scope and Limits of the Drive towards Global Uniformity. Cambridge: Polity Press, 1996.

${ }^{46}$ SAID, Edward. Orientalism. Nova York: Vintage, 1994.

${ }^{47}$ GALVÃO, Carlos. Autocracia, ressentimento e engajamento político no principado romano. In: BRESCIANI, Stella; NAXARA, Márcia (Orgs.). Memória (res)sentimento, indagaçōes sobre uma questão sensivel, op. cit., p. 317.
} 
Essa postura é próxima da perspectiva de Ansart de que se reflita sobre as consequências do ressentimento, ou seja, a criação de crenças e imaginários, além das açôes práticas. Só que Galvão vai um pouco mais além: o ressentimento não só tem consequências práticas e simbólicas, mas ele pode ser um agente ativo na estruturação de comportamentos políticos, ou seja, seria um ressentimento estruturante. É a relação entre o ressentimento e o habitus de Bourdieu, promovendo a ênfase na ação e não na imobilizaçáo provocada por esse sentimento. $\mathrm{O}$ caso que pretendo explicar, o dos ressentimentos antilusitanos, permite-nos juntar as duas interpretaçôes (a de Galvão e de Ansart) e fazer ver tanto a prática causada pelo ressentimento (Galvão) quanto seu produto simbólico (Ansart) como estruturantes da ação em todos os sentidos. O ressentimento estrutura a ação dos oprimidos e de parte da elite brasileira e também orquestra a construção de um universo simbólico contra o inimigo, que foi devidamente manipulado por essas forças da elite, impondo seu ressentimento como estruturante da imagem da nação na forma que lhe interessa.

Haroche, ${ }^{48}$ por sua vez, recorre a outro conjunto de autores para pensar o ressentimento, no caso, os trabalhos de Erich Fromm, Strauss, Arendt e Elias. A reflexão da autora e o uso desses autores remetem ao tema escolhido para pensar o ressentimento, o nazismo. As análises de Fromm têm como alvo a psicologia do nazismo, análises que Elias retoma, buscando compreender como a "personalidade social" das classes médias alemãs encorajava o desejo de submissão e de dominação. ${ }^{49}$ Fromm demonstra como grande parte dessas classes médias tinha um lugar em um sistema social estável, identificando-se com a monarquia. Sua imagem, seu sentido de existência se inscreve na submissão aos dominantes. O fim da Primeira Guerra transformou radicalmente aquela realidade e desmoronou o status desse grupo. Estavam dadas as condições para o surgimento do ressentimento, que logo contaminou a sociedade alemã como um todo. Apoiado na análise de Strauss sobre o niilismo alemão, Fromm detém-se no desejo de submissão dessas classes médias e no ódio pelos fracos, componentes encorajados pelo nazismo. O que Ansart ${ }^{50}$ chamou de "porta-vozes do ressentimento" pode ser visto aqui com clareza.

Continuando sua reflexão, Haroche lembra como Hannah Arendt via nessa personalidade submissa incondicional a característica dos movimentos totalitários. Arendt retrata a personalidade do homem totalitário: submissão às regras, falta de classificação, inutilidade, ausência de consciência, incapacidade de pensar e o mal radical. Elias retoma as reflexóes desses três autores (Strauss, Fromm e Arendt) e apresenta uma explicação para a gênese dos mecanismos do ressentimento: o clima geral seria fruto de uma mistura de tipos específicos de estruturas sociais e das personalidades — que é "parte inerente aos ideais do ego, da for-

\footnotetext{
${ }^{48}$ HAROCHE, Claudine. Elementos para uma antropologia política do ressentimento: laços emocionais e progressos políticos, op. cit.

${ }^{49}$ Ibidem, p. 336.

${ }^{50}$ ANSART, Pierre. História e memória dos ressentimentos, op. cit.
} 
mação da consciência e dos códigos de comportamento. ${ }^{51} \mathrm{O}$ ressentimento também é visto como manifestação social que modela a formação de personalidades por Galvão, ${ }^{52}$ estando inscrito nos movimentos de confrontação social, nas disputas de classes. Konstan ${ }^{53} \operatorname{também~}^{2}$ considera que a experiência emocional é eminentemente cultural. Postura semelhante à de Galvão, para quem as emoçóes são um idioma ou um código que "define e negocia relaçóes do eu com uma ordem social ou moral e cujo significado náo pode ser separado do papel que desempenham na interação social" ${ }^{54}$

Elias, que inspira a reflexão desses autores, considera que:

Um profundo ressentimento pode surgir (...) entre os membros da maioria, sobretudo entre aqueles que têm a impressão de que seu status está ameaçado, que creem ter perdido valor, que não se sentem mais em segurança. Esse ressentimento surge quando um grupo marginal socialmente inferior, desprezado e estigmatizado, está a ponto de exigir a igualdade não somente legal, mas também social; quando seus membros começam a ocupar, na sociedade majoritária, posições antes inacessíveis a eles..$^{55}$

É um desprezo pelos marginalizados da sociedade, um ressentimento que aparece como resposta inconsciente, fruto da angústia ignorada. Nesse ponto, é possível fazer comparaçóes com o modelo de ressentimento de Nietzsche, no seu desprezo pelos "inferiores". O ódio que vai se formando nas classes médias alemãs dirige-se não aos dominantes, mas àqueles que podiam se subtrair da situação humilhante imposta pela servilidade, ou seja, os judeus que não cultivaram a submissão patológica da maior parte daquela classe média. $\mathrm{O}$ ressentimento dirige-se, por parte da classe média nacionalista humilhada, aos que se furtaram dos mecanismos de poder, ou seja, nascido em uma relação, dirige-se a outro objeto.

O caso dos sentimentos antilusitanos no Brasil é uma confluência de ressentimentos: o da classe média branca brasileira contra imigrantes pobres brancos que, apesar disso, podem adentrar o mercado do comércio, restrito aos portugueses. Esse ressentimento é semelhante ao descrito por Elias. Mas o das classes não brancas é de outra ordem, em razão de se verem ainda mais rebaixadas em uma hierarquia social em que ocupavam a pior posição, entretanto, os mecanismos são semelhantes: os portugueses são apenas a evidência mais palpável de um ressentimento contra a humilhação extrema das classes pobres não brancas brasileiras, são o "bode expiatório" preferencial de um ressentimento de longa duração, fruto da estrutura social brasileira.

\footnotetext{
${ }^{51}$ HAROCHE, Claudine. Elementos para uma antropologia política do ressentimento: laços emocionais e progressos políticos, op. cit, p. 339.

${ }^{52}$ GALVÃO, Carlos. Autocracia, ressentimento e engajamento político no principado romano, op. cit.

${ }^{53}$ KONSTAN, David. Ressentimento — história de uma emoção, op. cit., p. 59.

${ }^{54}$ GALVÃO, Carlos. Autocracia, ressentimento e engajamento político no principado romano, op. cit., p. 318.

${ }^{55}$ NORBERT ELIAS apud HAROCHE, Claudine. Elementos para uma antropologia política do ressentimento: laços emocionais e progressos políticos, op. cit., p. 340.
} 
Neste ponto, chegamos à necessidade de pensar a ação propriamente dita das classes populares e das elites nas explosóes de violência causadas pelo ressentimento estruturante que permeava a sociedade brasileira. Ansart-Dourlen ${ }^{56}$ reflete sobre a relação entre ressentimento e práticas revolucionárias, ao mesmo tempo que avalia o problema da manipulação do ressentimento pelas ideologias totalitárias. A autora pensa em dois tipos de ressentimento: o "positivo", guiado pela razão, e o "negativo", que resulta em explosōes de paixôes raivosas. Para Zawadzki, ${ }^{57} \mathrm{o}$ ressentimento foi frequentemente associado a coisas que os pensadores repudiam: nacionalismo, racismo, totalitarismo. Assim, o bom ressentimento deveria ser sempre lembrado por porta-vozes, ${ }^{58}$ que manteriam a chama da indignação na condução de uma tentativa de transformação social. Ansart-Dourlen narra o caso de Marat, durante a Revolução Francesa, e o da resistência à ocupação alemã na França durante a Segunda Guerra.

O ressentimento antilusitano do final do XIX seria, sob vários aspectos, o ressentimento "negativo": não produziu transformação social, resultou em violências e foi manipulado pelos dominantes, de forma a não ameaçar a estrutura social. Em alguns momentos, teve uma dimensão revolucionária, como na Revolução Praieira (que também pretendia nacionalizar o comércio), mas foi duramente reprimido por uma estrutura social violentamente racializada. Foi manipulado porque a escolha dos portugueses como bode expiatório foi inflada por parte da elite ressentida, mas que não pretendia transformar a sociedade, apenas ter acesso ao nicho de mercado controlado pelos portugueses. A escolha destes como motivadores da penúria dos não brancos tirava de foco a própria estrutura social racializada, que era a verdadeira causadora do ressentimento. O grande porta-voz do sentimento antilusitano na elite era o jornal Jacobino, como demonstra Ribeiro ${ }^{59}$ (2000). Esse jornal liderava o movimento antilusitano, conhecido como jacobinismo, "movimento fortemente ligado à necessidade de consolidação da recém-inaugurada República, com aspectos notadamente nacionalistas e de exaltação da pátria”. ${ }^{60}$ Ora, o ressentimento da elite buscava construir uma ideia de nacionalidade antagônica àquela do império, profundamente ligada a Portugal. Como porta-vozes de um ressentimento que aparece como comum, as elites transformaram o ressentimento popular em instrumento do nacionalismo e tentaram afastar os perigos de revoltas contra as elites brancas.

Ribeiro $^{61}$ (1994) indica como o antilusitanismo aparecia de forma transversal às classes sociais cariocas durante a República Velha, dado o controle do comércio e bens em geral

\footnotetext{
${ }^{56}$ ANSART-DOURLEN, Michèle. O ressentimento - as modalidades de seu deslocamento nas práticas revolucionárias. Reflexóes sobre o uso da violência, op. cit, p. 351.

${ }^{57}$ ZAWADSKI, Paul. O ressentimento e a igualdade: contribuição para uma antropologia filosófica da democracia, op. cit.

${ }^{58}$ ANSART, Pierre. História e memória dos ressentimentos, op. cit.

${ }^{59}$ RIBEIRO, Gladys Sabina. A guerra dos portugueses no Rio de Janeiro no final do século XIX, op. cit.

${ }^{60}$ Ibidem, p. 68.

${ }^{61}$ RIBEIRO, Gladys Sabina. "Por que você veio encher o pandulho aqui?” Os portugueses, o antilusitanismo ea exploração das moradias populares no Rio de Janeiro da República Velha. Análise Social, v. XXIX, n. 127, p. 631-654, 1994.
} 
pelos portugueses. A crescente imigração portuguesa inchava o mercado de trabalho em desfavor dos não portugueses. Dos Santos Junior ${ }^{62}$ nos esclarece sobre a dimensão política e diplomática do antilusitanismo jacobino nesse momento, ilustrando as reaçóes do corpo diplomático português às críticas e ameaças dirigidas ao governo português e aos portugueses em geral no Brasil. O autor destaca como esse "grupo", na verdade, era um conjunto complexo de pessoas e interesses, com diferenças de classe, de radicalismo e projetos de poder. Destaca-se que o antilusitanismo, uma bandeira desse movimento, lhe era anterior, como vimos ao longo deste texto. A radicalização do antilusitanismo jacobino se deu com a crise econômica da década de 1890, marcada por uma hiperinflação, diretamente associada aos comerciantes portugueses pelas classes populares.

Ansart-Dourlen ${ }^{63}$ considera que o ressentimento pode ser o combustível de uma movimentação contra aquilo que oprime, servindo como estímulo para uma ação do dominado. Porém, pode ser orientado contra outros inimigos (imigrantes), reforçando a estrutura de dominação e fazendo com que algumas populaçóes sofram o papel de bode expiatório, como foi no caso do antilusitanismo. É nesse sentido que podemos dizer, seguindo Galvão, ${ }^{64}$ que o ressentimento antilusitano é estruturante na sociedade brasileira. Foi esse elemento que possibilitou, ou facilitou, a criação da nacionalidade e continua ainda a operar nesse sentido. Lembremos que a ideia de nação brasileira, no final do século XIX, tinha na população não branca seu grande problema. A questão era definir se era ou não possível uma nação com mestiços e negros. Sob essa perspectiva, cada piada de português que se conta é um reforço a mais na perpetuação desse ressentimento estruturante, mesmo que tenha assumido novas formas.

\section{Considerações finais}

$\mathrm{O}$ ressentimento antilusitano das classes não brancas explode em relação àqueles imigrantes portugueses pobres que competem diretamente no mercado de trabalho. ${ }^{65}$ Mas esse sentimento foi produzido pela estrutura social cruelmente racializada. O que poderia ser uma resistência causada pelo ressentimento virou um recalque que escolheu um alvo fácil, estimulado pelo próprio ressentimento das elites brancas e da classe média. Na perspectiva dessa classe, o ressentimento foi desenvolvido em uma dimensão de disputa pelo controle do comércio e pela construção de uma legitimação da nação republicana. Foram duas ordens de ressentimento que atingiram duas classes de portugueses diferenciadas, tendendo a homogeneizá-los.

${ }^{62}$ DOS SANTOS JÚNIOR, João Júlio Gomes. Jacobinismo, antilusitanismo e identidade nacional na República Velha. Historia, v. 2, n. 2, p. 107-122, 2011.

${ }^{63}$ ANSART-DOURLEN, Michèle. O ressentimento - as modalidades de seu deslocamento nas práticas revolucionárias. Reflexóes sobre o uso da violência, op. cit.

${ }^{64}$ GALVÃO, Carlos. Autocracia, ressentimento e engajamento político no principado romano, op. cit.

${ }^{65}$ ALENCASTRO, Luiz Felipe. Escravos e proletários, op. cit. 
O resultado da uniáo desses sentimentos, coordenado pela classe que servia de porta-voz por meio de seus jornais, foi a unificação do tratamento em relação ao bode expiatório, que ficou definitivamente marcado por um imaginário estereotipado. As caricaturas de época dáo uma ideia de como o português virou o alvo nacional, mostrando como uma das armas para dar vazão ao ressentimento é o humor. As piadas de português são fruto desse ressentimento duplo de classes muito distantes entre si. A perpetuação do imaginário relacionado ao ressentimento deu um dos elementos de respaldo para a legitimação da nacionalidade, criando uma figura antagônica comum, processo semelhante ao descrito por Ansart-Dourlen. ${ }^{66}$ Como o humor é um instrumento importante, o português virou parte da cultura nacional como alvo predileto.

Vimos neste ensaio, portanto, que a imagem estereotipada dos portugueses na forma como a conhecemos hoje é produto de uma reação dos negros e pardos populares, bem como de elites brancas, que corresponde à extrema racialização daquela situação de disputa no mercado de trabalho. Mas os sentimentos foram manipulados por essas elites e os estereótipos foram uma expressão simbólica de ressentimento da população mais oprimida do final do século XIX, os negros (ex-escravos, ex-libertos, pardos). É bom pôr em perspectiva essa produção simbólica e seus efeitos discriminatórios: ela movimentou os mesmos preceitos racializados com os quais se confrontavam os negros no Brasil do final do século XIX e é semelhante à produção de movimentos xenófobos na Europa atual. Ou seja, produz estereótipos de "longa duração" que impedem persistentemente o conhecimento sobre Portugal e os portugueses.

\section{Referências bibliográficas}

ALENCASTRO, Luis Felipe de. O trato dos viventes: formação do Brasil no Atlântico Sul. Sáo Paulo: Companhia das Letras, 2000. . Continuidade histórica do luso-brasileirismo. Novos Estudos Cebrap, n. 32, p. $77-$ 85, março 1992. . Escravos e proletários. Novos Estudos Cebrap, n. 21, p. 30-57, jul. 1988. . Le commerce des vivants: traite d'esclaves et "pax lusitana" dans l'atlantique sud. Tese (doutorado em história) — Universidade Paris X, Paris, 1986.

ALVES, Jorge Fernandes. Os brasileiros. Emigração e retorno no Porto oitocentista. Porto: Edição do Autor, 1994.

AMIN, Samir. Eurocentrism. Nova York: NYU Press, 1989.

\footnotetext{
${ }^{66}$ ANSART-DOURLEN, Michèle. O ressentimento - as modalidades de seu deslocamento nas práticas revolucionárias. Reflexôes sobre o uso da violência, op. cit.
} 
ANSART, Pierre. História e memória dos ressentimentos. In: BRESCIANI, Stella; NAXARA, Márcia (Orgs.). Memória (res)sentimento, indagaçóes sobre uma questão sensivel. Campinas: Ed. Unicamp, 2001.

ANSART-DOURLEN, Michèle. O ressentimento — as modalidades de seu deslocamento nas práticas revolucionárias. Reflexões sobre o uso da violência. In: BRESCIANI, Stella; NAXARA, Márcia (Orgs.). Memória (res)sentimento, indagaçóes sobre uma questão sensivel. Campinas: Ed. Unicamp, 2001.

BOURDIEU, Pierre. O poder simbólico. Lisboa: Difel, 1989.

CARVALHO, José Murilo de. Estudos do poder local no Brasil. Revista Brasileira de Estudos Políticos, n. 31, jul. 1968/jan. 1969, p. 231-248.

CAVALCANTI, Paulo. Eça de Queiróz, agitador no Brasil. 2. ed. São Paulo: Companhia Editora Nacional, 1966.

DOS SANTOS JÚNIOR, João Júlio Gomes. Jacobinismo, antilusitanismo e identidade nacional na República Velha. Historia, v. 2, n. 2, p. 107-122, 2011.

FELDMAN-BIANCO, Bela; BASTOS, Cristiana; ALMEIDA, Miguel Vale. (Coords.). Trânsitos coloniais: diálogos cruzados luso-brasileiros. Lisboa: Imprensa de Ciências Sociais, 2002.

FELDMAN-BIANCO, Bela. Brazilians in Portugal, Portuguese in Brazil: constructions of sameness and difference. Identities - Global Studies in Culture and Power, v. 8, n. 4, p. 607650, 2001.

FLORENTINO, Manolo; MACHADO, Cacilda. Miscigenação e exclusão do Rio de Janeiro c. 1800-1850. Oceanos, n. 44, p. 100-110, out/dez. 2000.

FLORENTINO, Manolo. Um comércio singular: tráfico e traficantes de africanos no Rio de Janeiro (1790-1830). Oceanos, n. 44, p. 40-58, out/dez. 2000.

FREUD, Sigmund. Civilization and its Discontents (1930 [1929]). In: FREUD, Sigmund. The Standard Edition of the Complete Psychological Works of Sigmund Freud. Volume XXI (1927-1931). 3. ed. Toronto: The Hogart Press Limited, 1968.

FREYRE, Gilberto. Casa grande e senzala: formação da família brasileira sob o regime de economia patriarcal. Rio de Janeiro: Record, 1990.

GALVÃO, Carlos. Autocracia, ressentimento e engajamento político no principado romano. In: BRESCIANI, Stella; NAXARA, Márcia (Orgs.). Memória (res)sentimento, indagaçóes sobre uma questão sensivel. Campinas: Ed. Unicamp, 2001.

HALL, Stuart. A identidade cultural na pós-modernidade. Rio de Janeiro: DP\&A, 2002.

HAROCHE, Claudine. Elementos para uma antropologia política do ressentimento: laços emocionais e progressos políticos. In: BRESCIANI, Stella; NAXARA, Márcia (Orgs.). Memória (res)sentimento, indagaçóes sobre uma questão sensivel. Campinas: Ed. Unicamp, 2001. KONSTAN, David. Ressentimento — história de uma emoção. In: BRESCIANI, Stella; 
NAXARA, Márcia (Orgs.). Memória (res)sentimento, indagaçóes sobre uma questão sensível. Campinas: Ed. Unicamp, 2001.

LATOUCHE, Serge. The Westernisation of the World. The Significance, Scope and Limits of the Drive towards Global Uniformity. Cambridge: Polity Press, 1996.

LESSA, Carlos. Nação e nacionalismo a partir da experiência brasileira. Estudos Avançados, v. 22, n. 62, p. 237-256, 2008.

MERTON, Robert King. Eléments de théorie et de méthode sociologique. Paris: Plon, 1965.

NIETZSCHE, Friederik. 3. ed. A genealogia da moral. Lisboa: Guimarães e C. A. Editores, 1976.

RIBEIRO, Gladys Sabina. “Brasileiros, vamos a eles!”: identidade nacional e controle social no primeiro reinado. Ler História, n. 27/28, p. 103-125, 1995.

. "Ser português" ou "ser brasileiro"?: algumas consideraçóes sobre o primeiro reinado. Ler História, n. 25, p. 27-57, 1994.

. "Por que você veio encher o pandulho aqui?" Os portugueses, o antilusitanismo e a exploração das moradias populares no Rio de Janeiro da República Velha. Análise Social, v. XXIX, n. 127, p. 631-654, 1994.

- A guerra dos portugueses no Rio de Janeiro no final do século XIX. Oceanos, n. 44, p. 68-84, out./dez. 2000.

- A liberdade em construçâo: identidade nacional e conflitos antilusitanos no primeiro reinado. Tese (doutorado) — Unicamp, Campinas, 1997.

- Mata galegos. Os portugueses e os conflitos de trabalho na República Velha. São Paulo: Brasiliense, 1990.

- Pés-de-chumbo e garrafeiros: conflitos e tensões nas ruas do Rio de Janeiro no Primeiro reinado (1822-1831). Revista Brasileira de História, v. 12, n. 23/24, p. 141-165,1992. ROWLAND, Robert. Portugueses no Brasil independente: processos e representaçóes. Oceanos, n. 44, p. 8-20, out./dez. 2000.

SAID, Edward. Orientalism. Nova York: Vintage, 1994.

SCHELER, Max. Da reviravolta dos valores. Petrópolis, RJ: Vozes, 1994 [1972].

SERRÃO, Joel. A emigração portuguesa: sondagem histórica. Lisboa: Livros Horizonte, 1982. SILVA, Eduardo da. Dom Obá II d'África, o príncipe do povo: vida, tempo e pensamento de um homem livre de cor. São Paulo: Companhia das Letras, 1997.

VIEIRA, Nelson H. Brasil e Portugal, a imagem recíproca: o mito e a realidade na expressão literária. Lisboa: Ministério da Educação — Instituto de Cultura e Língua Portuguesa, 1991. ZAWADSKI, Paul. O ressentimento e a igualdade: contribuição para uma antropologia filosófica da democracia. In: BRESCIANI, Stella; NAXARA, Márcia (Orgs.). Memória (res) sentimento, indagaçôes sobre uma questão sensivel. Campinas: Ed. Unicamp, 2001. 


\section{RESSENTIMENTOS E ESTEREÓTIPOS: ENSAIO SOBRE AS REPRESENTAÇÓES A RESPEITO DO PORTUGUÊS NO BRASIL (SÉCULO XIX)}

Igor José de Renó Machado

\section{Como citar}

MACHADO, Igor José de Renó. Ressentimentos e estereótipos: ensaio sobre as representaçôes a respeito do português no Brasil (século XIX). Topoi. Revista de História, Rio de Janeiro, v. 19, n. 37, p. 125-143, jan./abr. 2018. Disponível em: <www.revistatopoi.org>. 